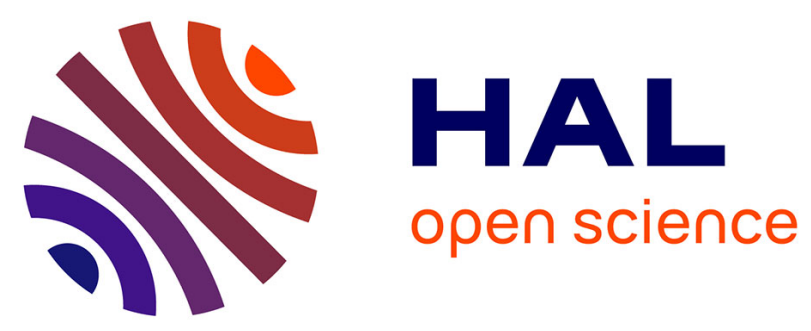

\title{
Visual Artists' Professional Situations and Trajectories. Between Institutions and the Market
}

Pierre Bataille, Johannes Hedinger, Olivier Moeschler

\section{To cite this version:}

Pierre Bataille, Johannes Hedinger, Olivier Moeschler. Visual Artists' Professional Situations and Trajectories. Between Institutions and the Market. A. Glauser; P. Holder; T. Mazzurana; O. Moeschler; V. Rolle; F. Schultheis. The Sociology of Arts and Markets - New Developments and Persistent Patterns, Springer, pp.97-128, 2020, 10.1007/978-3-030-39013-6_5 . hal-02874574

\section{HAL Id: hal-02874574 https://hal.science/hal-02874574}

Submitted on 18 Jun 2020

HAL is a multi-disciplinary open access archive for the deposit and dissemination of scientific research documents, whether they are published or not. The documents may come from teaching and research institutions in France or abroad, or from public or private research centers.
L'archive ouverte pluridisciplinaire HAL, est destinée au dépôt et à la diffusion de documents scientifiques de niveau recherche, publiés ou non, émanant des établissements d'enseignement et de recherche français ou étrangers, des laboratoires publics ou privés. 


\title{
Visual Artists' Professional Situations and Trajectories. Between Institutions and the Market
}

Pierre BATAILLE (University Grenoble-Alpes), Johannes M. HEDINGER (Zurich University of the Arts) and Olivier MOESCHLER (University of Lausanne)

\begin{abstract}
Since the $19^{\text {th }}$ century and romanticism, the "singularity regime" (Nathalie Heinich) - which highlights the vocation and achievements of the individual creator - informs the artist figure. Recently, as if echoing this romantic imagery, the representation of the artist as an entrepreneur has been more and more put forward in the artistic sector itself, including in art schools and the creative industries. At the same time, the model of the artist as a worker (Pierre-Michel Menger), as part of competitive artistic fields (Pierre Bourdieu) and as embedded in collaborative "art worlds" (Howard Becker), stresses the competitive as well as the collective and collaborative dimension of artistic creation. Who exactly are visual artists in Switzerland today? What is or are the self-representation(s) of contemporary visual artists? What are their socio-demographic profiles - notably in terms of gender - and their link to professional or personal trajectories and positions? Do artists manage to live from their artistic production? To what extent are they integrated into the artistic market? And how do they define themselves? This contribution draws on a national inquiry with a quantitative online questionnaire on more than 450 artists in the visual field living and/ or working in Switzerland. The results outline the professional contours of today's visual artists, their novelties and permanencies, in a field structured by three poles - market logics, institutional support and non-integration. It highlights the strong role of the gender variable, as well as the dilemmas, contradictions and paradoxes that characterise todays artists' self-perception and condition.
\end{abstract}

Référence originale: Bataille, P., Hedinger, J. M., \& Moeschler, O. (2020). Visual Artists' Professional Situations and Trajectories Between Institutions and the Market. In A. Glauser, P. Holder, T. Mazzurana, O. Moeschler, V. Rolle, \& F. Schultheis (Eds.), The Sociology of Arts and Markets (pp. 97-128). Springer International Publishing. https://doi.org/10.1007/978-3-030-39013-6 5

\section{Introduction}

Following $19^{\text {th }}$ century romanticism, the modern figure of the artist has been associated with the idea of singularity, which highlights the vocation and achievements of the individual creator. Several authors have described the passage of different art forms - among them visual arts - into the "singularity regime" which, according to Nathalie Heinich (2005), characterises the modern artists' 
condition. There has been a shift from an often collective, unsigned craft to a regime which puts forward the vocation as well as the individually created and signed art work, a passage from the Académie and its Salon to the art market and to the modern, solitary but not individualistic, gifted and genius-like but uninterested artist.

However, while the ethereal imagery of the "artiste maudit" still persists, the model of the artist as an entrepreneur has emerged and stresses the strategic, rational and competitive dimension of artistic creation. As early as 1980, Lee Caplin has proposed a portrait of the artist as an "entrepreneur" (Caplin 1980). Today, the "artist entrepreneur" figure is more and more present, in the artistic field itself, including in art schools and cultural policy agencies, but also in the wider society, suggesting a very close relationship between artists and the market or commercial rationales (Boltanski and Chiapello 1999; Reckwitz 2012; Grau 2013; Dockx and Gielen 2015; Jacobs 2016; Henning, Schultheis and Thomä 2019) ${ }^{1}$. An author like Katja Lindqvist explores the similarities and differences between artists and entrepreneurs, addressing issues such as their traditionally ascribed characteristics, norm and rule breaking behaviours, and functions in the process of bringing original ideas into the realm of consumers and larger society (Lindqvist 2011). In the specific sector of visual and notably contemporary art, this model is strongly linked to the globalisation, expansion and reconfiguration of the art market as well as the hybridisation of artistic works and production processes themselves in a global context (Bydler 2004, Weibel 2007, Belting 2009, 2011 and 2013, Glauser 2009). More recently, some authors pointed out the "interpenetration" between this recent entrepreneurial imagery and the artistic singularity regime. Entrepreneurship appears thus to be a continuation and an inversion of the romantic artist figure - although this "introduction of capitalist logics" happens for the moment more at the paradigmatic level than as a regime, since it mainly applies to the few very internationally successful artists (Borja and Sofio 2009: 23, 24).At the same time, sociological analyses has repeatedly shown the determinisms that affect artistic work and careers, of which the entrepreneurial ideal and constraint is nothing but a new component. From a sociological perspective art is a professional activity (almost) like any other. While Eliot Freidson saw artistic professions, linked to "vocation", as a "challenge" for sociological analyses and as being fundamentally different from classical professions (Freidson 1986) and even argued that they "cannot be professions" (Freidson 1994), authors like Howard Becker (1982) have described the "art worlds" as just another work sector, with their conventions and "cooperation chains", highlighting the role of the "reinforcement personnel" necessary for the production, distribution and reception of artworks. The paradigm of the artist as a rational "worker" has then been promoted by Pierre-Michel Menger, who linked the changes in the perception and forms of artistic work to the "metamorphoses of capitalism" (Menger 2002). Asking "who has created the

1 Among many examples of an indigenous discourse showing the rise of explicit merchant strategies in the arts, some years ago, ten artists explained in an internet publication "how they became art entrepreneurs" and how an artist can "use his or her creativity as a jumping-off point for creating a business" (Bram 2011). More recently, the Internet site "Small Business Trends" identified a "trend of the artist entrepreneur" and discussed the possibilities of "combining entrepreneurship with art" (Campbell 2017). An internet site entitled TheArtistEntrepreneur is fully dedicated to the theme: citing Andy Warhol saying that "Making money is art", its mission is to "empower visual artists and art organisations to challenge their status quo" and to "build creatively and financially fulfilling businesses" (online: http://theartistentrepreneur.com/home\#welcome-1). 
creators", Pierre Bourdieu (1984) has traced back the sociohistorical process leading to the "autonomisation" process of relatively autonomous "cultural production fields”, for example in literature in $19^{\text {th }}$ century France, structured by certain "rules of art" (Bourdieu 1996) and, also, a high degree of competition between artistic producers equipped with unequal capitals or resources.

Visual arts, where the passage "from the painter to the artist" (Heinich 1993) has been well studied, like cinema, literature or many musical genres, is a field which is known for being closer to the market than highly subsidised arts like theatre or classical music. Like all modern art fields, it is a highly competitive sector. Authors have analysed the highly unequal possibilities offered to artists on the national or international art market depending on their profile and strategies, for example according to nationality (Quemin 2014). It is also known for a long time that there are various and unequal gendered ways to professionalize in visual arts (see the pioneer paper of Pasquier 1983). In Switzerland, there have been few sociological studies on visual artists, except for reports on Swiss cultural and creative industries, in which visual arts are one of the "sectors" covered (see f.e. Weckerle and Grand 2018). Recently, Isabelle Moroni (2017) showed in a qualitative study on mobility of visual artists of the canton of Valais how the spatial mobility demanded by the contemporary art market imposes a norm of flexibility, availability and adaptability. Moroni shows that this need of constant redefinition of the self thus occurs even in peripheral regions - but can not equally be fulfilled according to the aesthetic posture claimed, the "cosmopolitan" capital acquired by the artists and, also, to gender. At the same time, it is in visual arts that the neoliberal model of the successful "artist entrepreneur" is maybe the more clearly observable, with artistic figures such Jeff Koons or Damien Hirst (Borja and Sofio 2009).

So, torn between autonomy and market logics, and confronted to persistent sociological determinisms: who are the visual artists today? What is the selfunderstanding of contemporary artists, what are their living conditions? What are their professional and personal situation? Why did they become artists, and how do they work? How do they make a living from their artistic activities and how are they inserted into the art market? Finally, can we observe a link between the various professional situations of the visuals artists and their self-perceptions in relation to artistic autonomy and market logics? This contribution aims at grasping the challenges that today's artists face, for the specific field of Swiss visual arts. We will analyse how the ways of being an "artist" are undergoing a significant evolution in the light of trends such as the globalisation and reconfiguration of the art market, the hybridisation of artistic works and production processes, the reduction of public funding and the emergence of new social expectations addressed to artists. We aim at approaching contemporary artists' situation, in an age where artistic living and working conditions seem at a crossroads, with market logics playing a more and more important role.

After the description of our general theoretical setting, our sample and analytic strategy, the chapter presents several results exploring the tension between institutions and the market in professional situations and trajectories, notably by mobilizing a gender perspective. The text ends with a conclusion which synthetises the main results and shows their relevance for further research on art and artists in the market. 


\section{Inquiry and respondents sample}

The analysis draws on a survey entitled "The New Artist" lead by the ZHdK (Zurich University of the Arts) in 2016-2017. The data which constitutes the bases for this contribution results from a national inquiry addressed to artists in the field of visual arts (painting, sculpture, installations,...) between October 2016 and February 2017.

The invitation to fill out the form was distributed in art associations, art schools and art institutes ${ }^{2}$. With the online questionnaire, we gathered information on 15 socio-demographic and 25 thematic questions about the representation of artistic work and the artist public figure and situation. Some of the latter aimed at describing the "objective" position or trajectory of the respondent ${ }^{3}$, while others referred to their self-perception and representations ${ }^{4}$. On the whole, 457 valid responses of visual artists in the whole country were registered into the e-survey device $^{5}$. A comparison with existing statistical data on the Swiss visual artists population (estimated at more or less 4,500 individuals), shows that around $10 \%$ of Swiss visual artists' population have been interrogated ${ }^{6}$ The comparison of our sample's sociodemographic profile with the whole Swiss visual artist population's profile and the Swiss workforce profile (Table1) allows to evaluate its characteristics and its representativeness. ${ }^{7}$

2 The mail and flyer invitation was disseminated in or via the following venues: SIK Swiss Institute for Art Research, the Swiss visual artists' association Visarte, SARN (Swiss Artistic Research Network), ZHdK and other schools of visual arts in Switzerland, as well as the magazines Kunstbulletin and Schweizer Kunstverein.

3 These were questions on the incomes generated out of the artistic activity, who finances his/her artwork and to what percentage, how he/she makes a living, on how he/she networks in the art scene, on work-life balance, the professional activity of his/her partner or how many close friends are artists.

4 The more subjective questions focussed on the reasons why the respondent became an artist, which other profession he/she would have chosen, how he/she describes his/her profession in official documents, the attributes that apply most for him- or herself, the elements that characterise a successful artist in his/her opinion or the role or function of an artist in society today. These closed questions all proposed preformatted items (plus an "other"-option).

5 For more information on the project, its documentation, the questionnaire and the general descriptive results, see: http://thenewartist.net/en/.

6 The source for these comparisons is the Swiss Labor Force Survey (SLSP). For the Swiss visual artists, a separated data exploitation furnished by the Federal Statistical Office (FSO) has been used on persons who work as visual artists in their primary and/or secondary professional activity, in analogy (as we'll see) to our sample.

7 The source for these comparisons is the Swiss Labor Force Survey (SLSP). For the Swiss visual artists, a separated data exploitation furnished by the Federal Statistical Office (FSO) has been used on persons who work as visual artists in their primary and/or secondary professional activity, in analogy (as we'll see) to our sample. 
Table 1: Comparison of the socio-demographic profile of visual artists (respondents sample),

Swiss visual artists and Swiss working population

\begin{tabular}{lcccc}
\hline & & $\begin{array}{c}\text { Visual artists } \\
\text { (respondents) }\end{array}$ & $\begin{array}{c}\text { Swiss visual artists } \\
\text { (SLSP) }\end{array}$ & $\begin{array}{c}\text { Swiss working pop. } \\
\text { (SLSP) }\end{array}$ \\
\hline Sex & & & \\
& Male & 39.7 & 64.3 & 53.5 \\
& Female & 60.3 & 35.7 & 46.5
\end{tabular}

Age

$15-24$

4.8

3.1

12.0

25-39

20.1

18.9

32.5

40-54

33.7

36.8

34.6

55-64

25.8

21.6

16.9

$65+$

15.5

18.5

4.0

Average age

50.2

51.1

41.8

Diploma

Other

42.0

56.8

58.5

Tertiary

58.0

43.2

41.5

Nationality

Swiss
Other

93.0

84.7

74.2

7.0

15.4

25.8

n

457

4500

4675000

Swiss working population (2018) and Swiss visual artists (pooling 2010-2018): Swiss Labour Force Survey (SLFS)

Table 1 shows that women are overrepresented in the sample: six out of ten of the interviewees (60\%) are female (see Table 1). In the overall Swiss working population, this percentage is clearly lower, and this is even more the case among the Swiss visual artists, where men are strongly overrepresented ${ }^{8}$. This trend in our sample may result to the fact that in art schools, where the questionnaire has largely circulated, the population is more feminised, a fact that has been verified in many European countries (Provansal 2018) ${ }^{9}$. Moreover, this feminisation reminds us that whereas the elite of art domains almost always is masculine (Buscato 2007),

8 For sex, age and nationality of the Swiss working population, see FSO (2018): https://www.bfs.admin.ch/bfs/fr/ home/statistiques/travail-remuneration/enquetes/espa/publications-resultats.assetdetail.9366518.html.

9 It is the case in Swiss tertiary art schools for the students - although only slightly: 54\% of the students in art schools are female - as well as for the leading educational, the research and the administrative-technical personnel, where the percentage of women is over the average in art schools. See FSO (2018-2019): https://www.bfs.admin.ch/bfs/en/home/statistics/education-science/pupils-students/tertiary-higher- 
notably in visual arts (Quemin 2013), it is not the case of the whole artistic population. The sex distribution according to the age categories confirms this impression: while $60 \%-70 \%$ of the respondents are female from 19 to 59 , from 60 years onwards it sinks to $45 \%-50 \%$. The older the respondents, i.e. the ones that have been able to "survive" professionally in this difficult environment, are thus more likely to be men. This over-representation of women in our sample can also be the consequence of the dissemination of our survey in the institutional pole of the art sector - which is, as we'll see, more invested by women. Last but not least, it also known that women tend to be more responsive to inquiries. The structure of our interviewees' sample according to age may be surprising at first glance. Half of the sample (49\%) falls into the "middle" category of the 41-60 years old, and the largest 10-years age slice is 50-59 (29\% of the sample; see table in annex). The average age is 50.2 years: this is far more than the active population (41.8 years ${ }^{10}$ ), but corresponds almost exactly to the average age of Swiss visual artists (51.1 years). So in this case, our interviewees seem to be the reflection of an effective high age of this visual artists' population - as it can also be an effect from the survey design, as younger artists may have been less ready to fill out the questionnaire and to adopt the self-reflexive position it implied.This first results also show that the interviewees are highly educated $-58 \%$ have a university degree or equivalent, which is much more (actually the opposite) in regard to the Swiss workforce ${ }^{11}$. Such overrepresentation of tertiary graduates is partly due to our inquiry dispositive (mainly situated in art schools). It's also well known that higher educated are more likely to respond to surveys (see f.e. Le Feuvre et al. 2018). Nevertheless, one may also think that this echoes the tertiarisation of the sector ${ }^{12}$.

Finally, exactly three quarters (75\%) of the respondents are native-born Swiss citizens, $14 \%$ are naturalised Swiss citizens, about $4 \%$ are Swiss citizens living abroad and only $7 \%$ are foreign citizens who, according to the survey setting, at least work in Switzerland. In the end, 93\% have the Swiss nationality (table 1). This structure of origin is without surprise very different from the one of the overall workers' population in Switzerland, of whom one quarter (26\%) are foreigners, and of the Swiss visual artists survey respondents (15\%). Regarding the linguistic regions, the German speaking interviewees are clearly overrepresented: $82 \%$ of the visual artists answered in German, while around two thirds of the general population speaks German or dialect, probably echoing the fact that the study was initiated in Zurich. 15\% of the interviewees answered in French (whereas around $25 \%$ of the population speak French), corroborating the underrepresentation of the Latin part of Switzerland ${ }^{13}$.

To sum up, our sample of Swiss visual artists is feminised, older, much higher educated and much more "Swiss" than the overall national working population as well as than the Swiss visual artists population, to which it resembles most in

10 See FSO (2018): https://www.bfs.admin.ch/bfs/fr/home/statistiques/travail-remuneration/activiteprofessionnelle-temps-travail/personnes-actives/age-moyen-population-active.assetdetail.7206209.html.

11 See FSO (2018): https://www.bfs.admin.ch/bfs/fr/home/statistiques/travail-remuneration/activiteprofessionnelle-temps-travail/personnes-actives/niveau-formation.assetdetail.8226421.html.

12 See FSO (2018): https://www.bfs.admin.ch/bfs/fr/home/statistiques/travail-remuneration/activiteprofessionnelle-temps-travail/personnes-actives/niveau-formation.assetdetail.8226421.html.

13 Only $1.4 \%$ of the respondents live in Ticino, against around $4 \%$ of the Swiss population. 
terms of age.

\section{Method}

In order to account for the different ways of practicing the visual arts professionally in Switzerland, the social determinants of these ways of exercising and the consequences of this articulation in terms of self-representation of what "being an artist" means in the Swiss case studied, we favoured a modelling articulating specific multiple correspondence analysis (or ACM; Le Roux and Rouanet 2010) and clustering algorithms (Studer 2013).

Our aim is, first of all, to visualize the space of professional positions observed among the visual artists interviewed by identifying the different types of professionalisms that polarize the professional space and what they imply in terms of relations with art institutions, the art market and the State. Once the structuring of professional practices and careers in the Swiss visual arts identified, we propose to analyse the "ingredients" (Bidart, Longo and Mendez 2013) that seem to favour access to one or the other of the poles of the professional space - including gender, but also educational capital, social capital or age. Finally, we will see to what extent being located at one of the various poles of the professional space informs the visual artists' self-representation on the basis of the more subjective questions, that is the meaning given to "being an artist", the potential determinants of success and the social function of artistic activities. 
Table 2: Active modalities

\begin{tabular}{lll}
\hline Variables \& modalities & $\mathrm{N}$ & $\%$ \\
\hline Sources of income & & \\
Art & 126 & 27.6 \\
Dayjob (cult.) & 196 & 42.9 \\
Dayjob (non-cult.) & 158 & 34.6 \\
Family & 155 & 33.9 \\
Foundation & 85 & 18.6 \\
Savings & 86 & 18.8 \\
Social benefits & 34 & 7.4 \\
Who finances art activities & & \\
Self-financed & 396 & 86.7 \\
Pre-financing from galleries & 44 & 9.6 \\
Subscriptions (sales) & 154 & 33.7 \\
Donors, patrons & 79 & 17.3 \\
Foundations & 136 & 29.8 \\
Sponsoring & 59 & 12.9 \\
Public/government funding & 181 & 39.6 \\
Art institutions, museums & 152 & 33.3 \\
Other & 59 & 12.9 \\
Income from art. activities & & \\
>40,000 CHF per year & 33 & 7.2 \\
40,000 CHF per year & 46 & 10.1 \\
20,000 CHF per year & 89 & 19.5 \\
10,000 CHF per year & 73 & 16 \\
5,000 CHF per year & 150 & 32.8 \\
NR & 66 & 14.4 \\
\hline Total & 457 & \\
\hline
\end{tabular}

The variables chosen to construct the professional positions' space via the ACM the so-called "active" variables - are presented in Table 2. The three of them document, for each of the individuals questioned, the sources of income assuring the daily living expenses, the way in which artistic activities are funded, and the level of income earned per year from artistic activities.

Our "illustrative" variables provide information on the socio-demographic characteristics of the individuals interviewed (sex, diploma, age, partner's occupation, proportion of people identified as "artists" among close friends) are presented in the table in the annex ${ }^{14}$.

\section{Artistic precariousness}

The descriptive tables of these variables already call for some preliminary comments. In Table 2, we see that more than a third (35\%) of the interviewed artists have a non-cultural dayjob - i.e. a bread-and-butter job that has nothing to do with art or culture. And only $28 \%$ derive a significant income from their actual artistic practice. If these results are not necessarily surprising, they remind that for many artists - especially the most "ordinary" ones (Perrenoud and Bois 2017), who work at the lowest levels of the professional hierarchy - having a "double life" is relatively common (Lahire 2006, Throsby and Hollister 2003). Studies in theatre, music and 
literature did show that only the „multiplication of the self“ (Menger 1997) and the fact of being a "plural artist" (Bureau, Perrenoud and Shapiro 2009) with a subtle mixture of intra- and extra-sectorial polyvalence and/or "polyactivity" (Rolle and Moeschler 2014) leads to a relative professional stability and integration. Among our interviewees too, many are forced to conciliate professional spaces informed by totally different or even antagonistic symbolic logics. Being able to "make a living with art" appears to be relatively rare. In fact, being an artist only seldom is a fulltime activity: $35 \%$ work full time as artists (that is at rate of 75\%-100\%), while 56\% are part-time artists, who are mostly working either in the cultural and creative sector $(32 \%$, mainly as teachers, as art educators or mediators in the museum, exhibits and curatorial sector) or outside of it (13\%), sometimes also doing house work $(7 \%)$ or being in training (5\%). Almost $5 \%$ - or one out of twenty - are "occasional artists" working less than $30 \%$ on their art. One third of the artists (34\%) must also use the financial support of family members. This later remark also points out how different types of family capital can weigh in the launch and stabilization of such careers.

A significant proportion of respondents self-finances their creative activities in whole or in part $(87 \%)$, while a very small group $(10 \%)$ is regularly offered the opportunity to pre-sell their work to gallery owners. For one-third (33\%) of the respondents, the artistic activities yield less than CHF 5,000 per year, and overall for half of them (49\%) it does not exceed CHF 10,000. Only one fifth (20\%) earns around CHF 20,000, which is very little (as it means less than CHF 2,000 per month), and one out of then earns between CHF 20,000 up to CHF 40,000 of gross income with his or her art, a sum still far below the gross median Swiss salary of CHF 6,500 per month ${ }^{15}$. At the opposite end of the income scale, 7\% earn annually more than CHF 40,000, and only $1 \%$ reach up to $100,000 \mathrm{CHF}$ with their artistic production. In these oppositions, one can see the great disparity of income in the artistic sphere and the concentration of the most profitable activities in the hands of a small elite (Menger 2009). Art definitively does not bring wealth - in most cases, it is not sufficient as sole or even as main income. Although the two thirds of the visuals artists indicate that this amount is for themselves alone, these figures suggest a general situation of financial precariousness.

\section{A tripolar professional space of visual artists}

In this section, we propose to build the social space of visual artists on the basis of their economic living conditions. Figure 1 represents the relative proportion of the overall inertia of the model expressed by each dimensions of our factorial analysis, that is the variance rate by axes. The first two dimensions of our specific ACM contribute the most to the global inertia of the cloud (around 10\% each). It is therefore these two dimensions that we will retain for our analysis. 
Figure 1: ACM dimensions inertia

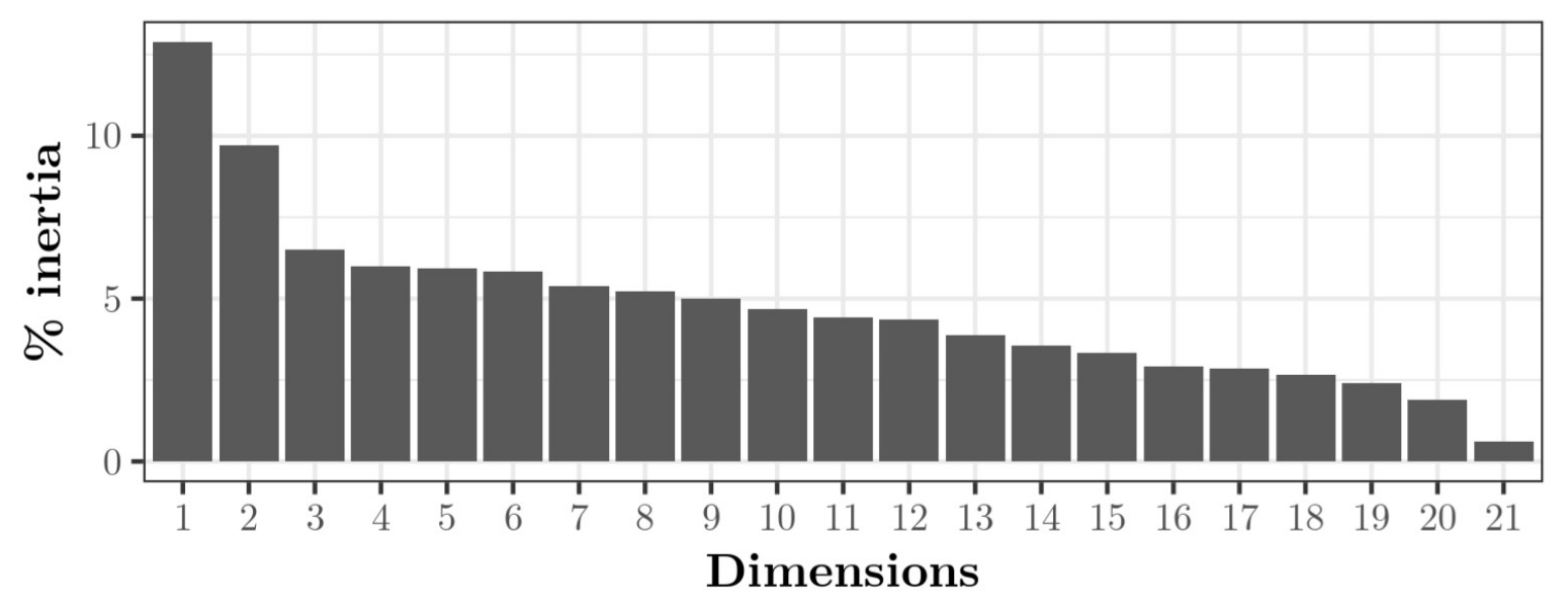

Figure 2 represents the modalities which contribute more than average (i.e. $2,7 \%$ ) to the axes as well as their location in the space of the professional positions thus constituted. 
Figure 2: Space of professional positions (Dim1 and Dim2)

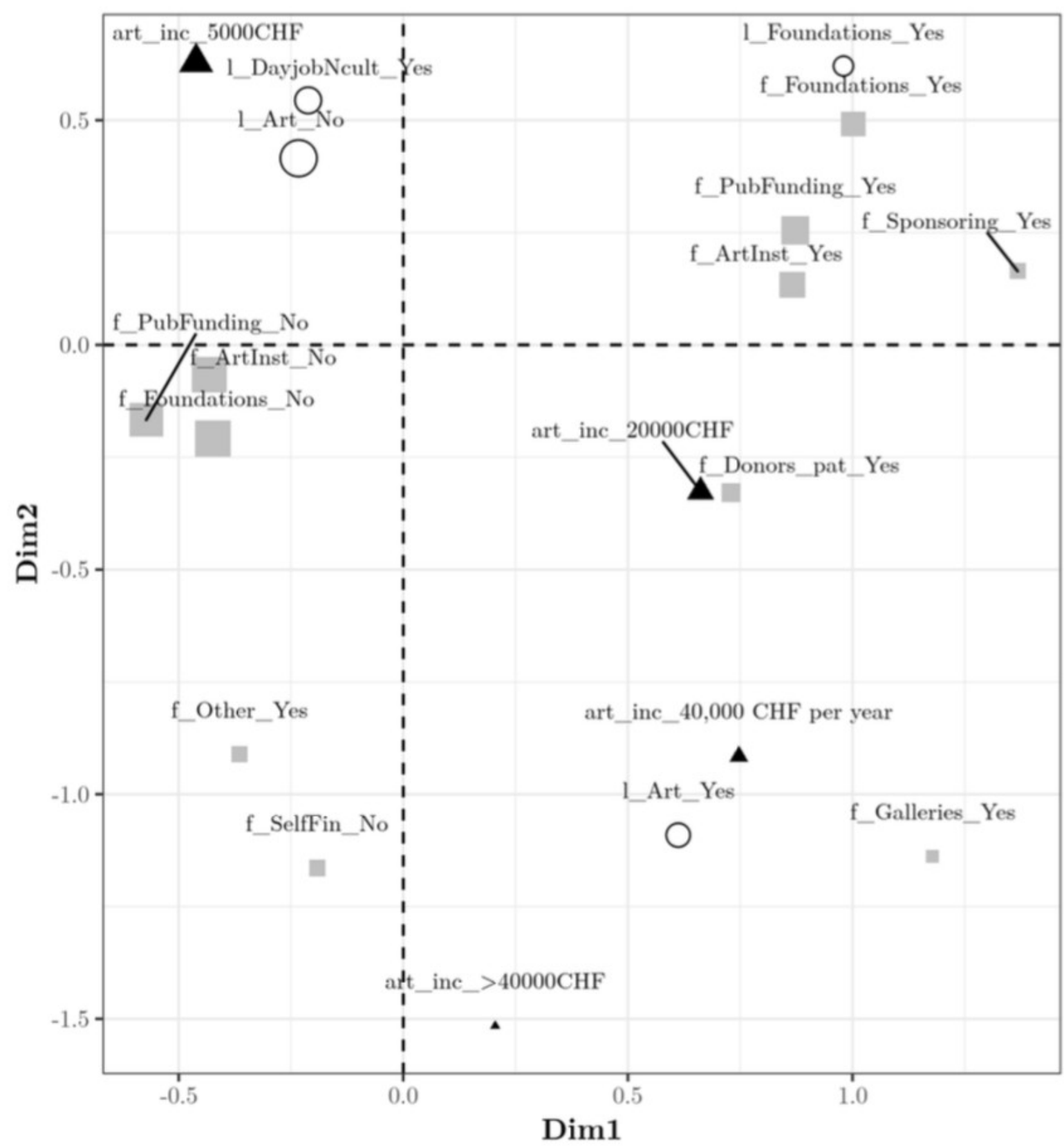

\footnotetext{
Variable types

- Make a living (1_)

who finances art (f_)

A Tot. art. income by year (art_inc_)
}

Having been supported by an institution (a gallery, a foundation, a patron...) and being able to make a living only through its art production polarises the individuals along the horizontal axis (first dimension). On the right are those who practice visual arts in a self-sufficient way (i.e. whose artistic activity is the main return of money). On the left of the axis are those who are little or not integrated into the professional environment (i.e. whose artistic production is not financed by public or private actors). 
The second dimension - the vertical one - opposes the respondents according to the volume of their earnings related to their professional activity in the visual arts community. At the top of the axis are individuals who draw relatively small amounts (CHF 5,000 per year) from their artistic activity and who potentially have a day job aside their artistic practice. This includes, in particular, artists whose professional activities have been funded by foundations or have produced some of their work through foundations action. The more people come down along this axis, the more they are making money through their artistic activities. At the bottom of the axis, we find the respondents who derive the most important income from their artistic works (more than 40,000 $\mathrm{CH}$ per year). Not so surprisingly for a field historically strongly linked to the market since it's autonomisation from the statecontrolled Académie with its Salon (Borja and Sofio 2009), it is those artists who are also most often followed by gallery owners who pre-finance all or part of their work that are living best out of their artistic production. As other studies revealed, today more than ever, artist selling their production on the art market through galleries or other private intermediaries (collectors, art fairs...) are the ones that are living best out of their artistic production (Graw 2010, Fasche 2013).

To sum up, our analysis shows a tripolarisation of the visual artists' professional space:

(1) At the top left is a pole of individuals little or weakly integrated into the professional space, which try a priori to return and stay there but have little access to legitimating and/or funding bodies;

(2) At the top right are the artists often supported by public or semi-public institutions (foundations, museums), who do not necessarily earn a lot of money with their artistic productions but who nevertheless have, we can assume, a recognition of their work.

(3) In the end, at the bottom are the visual artists who are in principle the most caught up in market logic, whose main support are the private galleries. These actors in the art market are the ones who earn the most revenue from the sale of their work.

\section{Artistic positions and paths: gender over age}

In the following section, we will look at if we can identify clusters out of our respondents according to their profile. Figure 3.A represents the distribution of the visual artists according to their relative membership to 5 clusters ${ }^{16}$ - again, the horizontal axes relates (from left to right) to the fact being more and more supported and/or able to live from one's art, while the horizontal axis refers (from top to bottom) to earning more and more from one's artistic activity. We draw concentration ellipses represent areas where at least $90 \%$ of individuals with the desired characteristic are situated - here membership of a particular cluster. When these ellipses are elongated, the longest axis represents the axis along which the individuals in question are mainly located. 
concentration ellipses (i.e. area where at least 90\% of individuals with the desired characteristic are situated) regarding to the cluster membership in order to visualize the main oppositions among clusters. :

- As already evoked at Figure 2, Cluster 1 gathers the individuals working in relation with the public institutions

- Cluster 3 regroups the artists mainly evolving on the art market

- In Cluster 4, one finds the marginalised and/or the new entrants

- The other two Clusters (2 and 5) occupy intermediate positions between the Cluster 4 and the other two, gathering artists located in grey areas - which are numerous in the markets of artistic work - on the periphery of the two main professionalisation poles (on the periphery of "institutional" artists for Cluster 2, on the periphery of "market" artists for Cluster 5).

Table 3 gives an idea of the weight of the different professional types identified by these clusters. The two clusters bringing together artists who earn all or most of their income through their artistic activity (the "institutional-oriented" Cluster 1 and the "market-oriented" Cluster 3) are the least numerous, while the cluster located at the pole of the "marginals" (Cluster 4) gathers 30\% or the largest groups of the interviewed artists, with the people not yet (or not anymore) integrated either to the institutional or the market pole - a distribution which illustrates the imbalance between the aspiring and the recognised in the fields of artistic work.

Figure 3.B then shows the location of the interviewed artists by gender. The women interviewed seem often located on an axis from the left of the graph to the upper right. This socio-gendered difference in location indicates that women tend to be slightly less likely than men to be in professional spaces organised around galleries and the art market - and thus make more career with the support of public institutions or foundations. Despite the fact that they make up the majority of the arts school enrolment in many European countries (Provansal 2018), in the end women artists have little access to the most lucrative segments of the labour market, as it appears here. This "gender gap" has been well identified internationally (Quemin 2013, Hassler 2017), including two decades ago in crosscountries comparative studies ${ }^{17}$, and is periodically thematised in the field itself ${ }^{18}$.

To explain the weaker presence of women visual artists at the "market-oriented" pole of professional space, scholars pointed out for the case of France the impact of intermediaries' arbitrations and their gendered representations, knowing that artistic notoriety is the result of the collective work of a series of intermediaries with whom the artists have interested and complex relations (Lizé, Naudier and Sofio 2014). These interactions are generally based on a "devaluation of practices [identified as] feminine" (Provansal 2018, 64-67), effectively excluding many female artists from galleries and private collections. The tacit injunction to maintain relations of seduction with these same intermediaries (often men) can also divert certain visual artists from the art markets in order to invest other spheres of

17 Cliché et al. (2001), comparing the situation of women in arts and media in 8 European countries, found out, for visual arts, that women artists' presence is at between around $30-60 \%$ of art students, $38 \%-45 \%$ of the artists and $3 \%-20 \%$ of lecturers and professors.

18 See for example in ARTnews, where an article pointed at the "major systemic problems" still rendering women's status and visibility difficult in the visual arts (Reilly 2015). 
activity - or, more importantly, to leave definitely their artistic career (ibid., 67-70; see, for the case of pop, rock or jazz music, Perrenoud and Chapuis 2016). Although we do not have empirical evidence to support these hypotheses in our case, we can think that similar mechanisms are at work in the Swiss visual arts' context and contribute to explain why women are stuck in that precise pole of the cultural field.

Figure 3: Clouds of individuals, cluster membership and sex
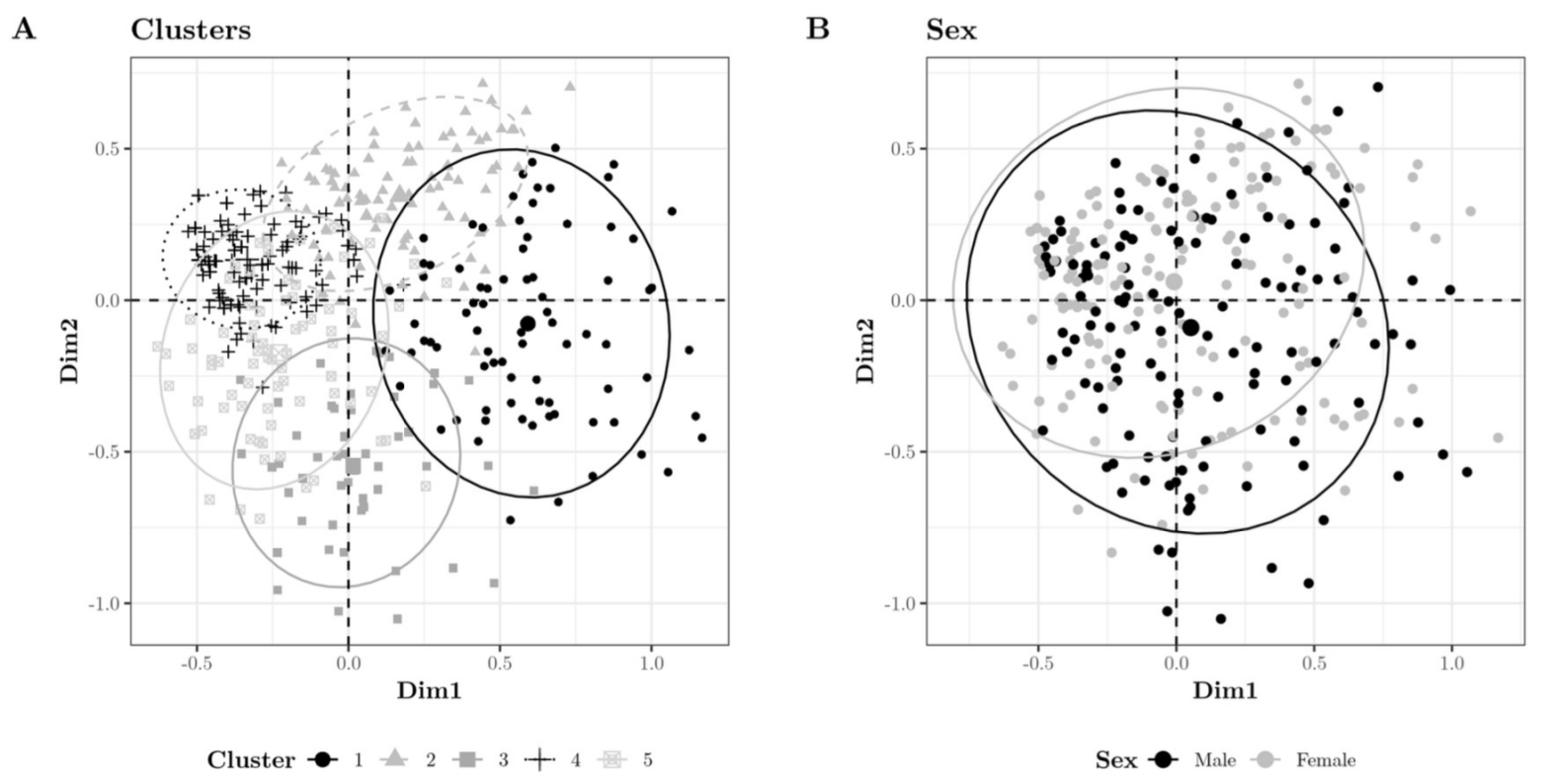

Table 3: Sample composition

\begin{tabular}{lrr}
\hline & $\%$ & $\mathrm{~N}$ \\
\hline Cluster 1 & 17.9 & 82 \\
Cluster 2 & 21.0 & 96 \\
Cluster 3 & 12.0 & 55 \\
Cluster 4 & 30.0 & 137 \\
Cluster 5 & 19.0 & 87 \\
\hline
\end{tabular}

As gender appears to be a structuring dimension of the tripolarisation of the professional space, we have carried out complementary analyses in order to better understand the variations in socio-demographic profile of the interviewed artists according to their position in the professional space. Figures 4 .A, B and C represent the location of individuals according to the classical variables of the level of education and age as well as for marital status (or, more precisely, the employment status of their partner, which notoriously influence the possibilities as an artist), and this, respectively, for men and women.

In Figure 4.A we see that the educational level doesn't seem to have a particular impact on the orientation of male careers (the circles are almost superposed). 
Women's access to the pole of "institutional" art however - the main way of professionalization concerning them - is partly conditioned by the fact of having obtained a diploma of higher education. This finding suggests that women who make a living through their artistic activities have greater educational capital than their male colleagues or competitors and, thus, appear slightly over-selected, in the sense that in the average they have a higher educational profile than their male counterparts (Buscatto 2009). Without precise data on the social origin of our respondents, it is impossible for us to know whether this over-selection of female visual artists doubles their social over-selection - even if nevertheless, access to the tertiary degree in Switzerland remains the preserve of children in the higher fractions of the social space, especially for women (Falcon 2013, 163-174). In view of this remarks, we can interpret the over-selection of female artists as the expression of the specific obstacles that hinder women's careers: to establish themselves durably in this professional space, women must be endowed with a greater volume of educational and social capital than those of men living in comparable environments.

Figure 4.B allows to point out another dimension of these gender inequalities, linked to age. We see here that age makes little difference in the group of men. Whether they are under thirty, between thirty or fifty or over sixty years of age, male visual artists may have the more or less same chances of being at one or the other of the three main poles of space professional. Coming to women, their position in the professional space differs greatly according to their age category. More precisely, those who are under thirty and those who are over sixty tend to concentrate at the upper-left of the graphic - i.e. the pole with little or no integration into the professional circuits and very little income derived from their artistic activities. This confinement of women belonging to the youngest and oldest categories to the least "lucrative" pole of the space could refer to the specific difficulties of women to establish themselves in the long term in artistic professional spaces (as it is the case for popular or jazz music in French speaking Switzerland: see Perrenoud et Chapuis 2016). This underlines the difficulties to access to careers - which is manifested by the fact that the aspirants stay longer in waiting positions before seeing their career take off - as well as the difficulty to maintain their professional commitment in the second part of their career. As other studies shown (Provansal 2018, Sinigaglia-Amadio and Sinigaglia 2015), the "injunction to conciliation" between family and professional life on the integration of women artists into the visual arts' community can be an explanatory factor of such gender inequalities. Even more so the Swiss gender regime stay strongly shape by a male breadwinner/female care giver model (Lefeuvre, et. al. 2018). This injunction is one more illustration of the fact - also studied for example in the field of universities and research - that "subjective decisions shall not be explained only by subjective factors" and that the configurations of actors around women artists, be they informal, are like the strongly "gendered organisations" found in more formal work situations and careers and observable even in apparently informal interactions (Beaufaÿs and Krais 2005: 53, 61). 
In line with these previous remarks, Figure 4.C highlights the importance of conjugal configurations in understanding the gendered orientation of professional careers. We can see that, in the case of male visual artists, "market-oriented careers" (the bottom-right of the graphic) are more common among individuals in a relationship with someone who does not work in the art worlds. Men in pairs with artists or cultural partners are more frequent at the pole of so-called "institutional" artists (at the upper-right). Differences are less pronounced for women visual artists (the circles are more concentric), and heterogamy (i.e. being with someone not belonging to the world of arts) seems less frequent, with seemingly more homogamous strategies (the larger "art" and "culture" circles) which are not directed towards the market pole (at the bottom-right). As we have no precise information on the type of the partners' jobs or on the labour division within the couples, we can make only do the hypothesis that, in order to settle permanently in the art markets - where the competition is particularly harsh and where yields are certainly higher but also more speculative - have support with a professional position more stable perhaps allows to consider more serenely risky professional strategies.

Figure 4: Clouds of individuals, diploma, age and partner situation
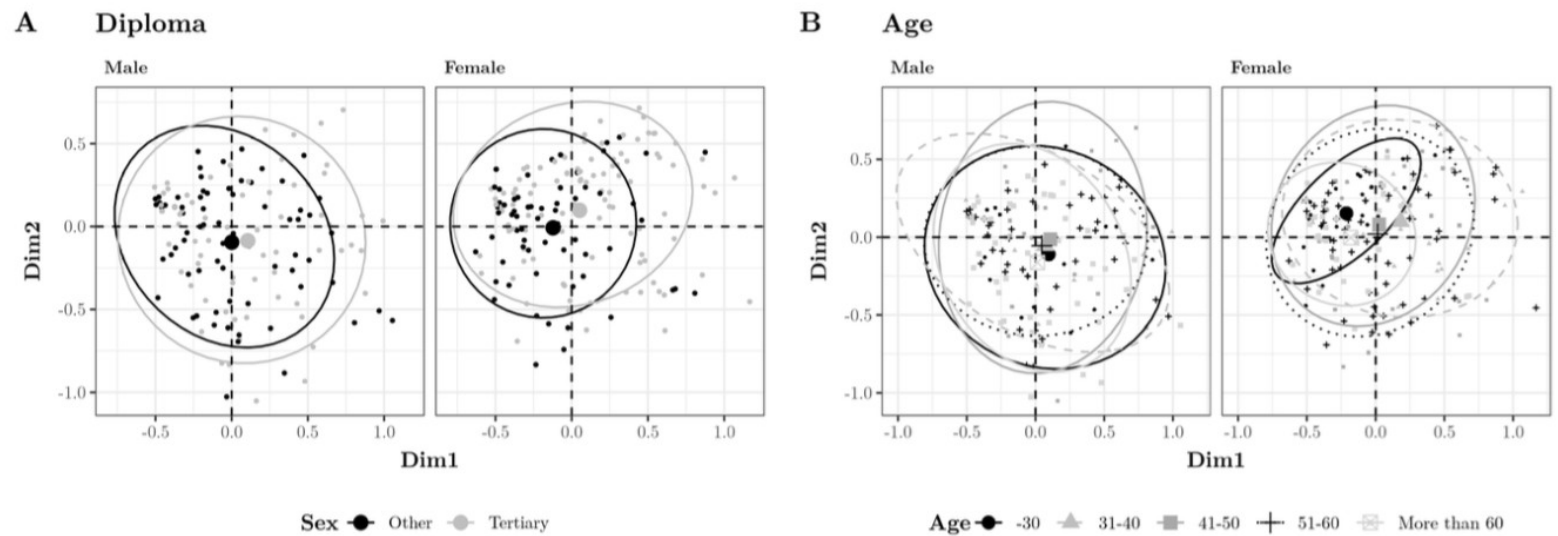

C Partner situation

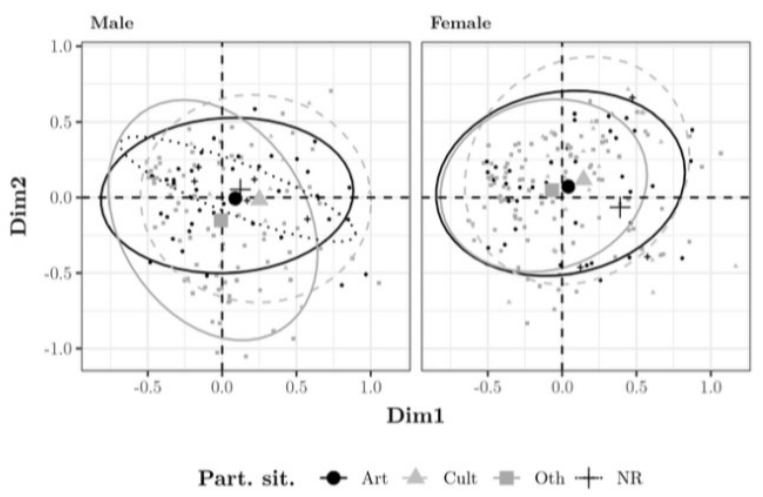

Age $--30=31-40-41-50+51-60=$ More than 60

Visual artists' self-representation: the persistence of a romantic self-image

Once we have grasped the logic that polarises the professional space and the elements of what differentiates careers and positions, it remains to be understood to what extent these differences in practices and the inequalities they cover affect the meaning ascribed by the artistic workers of the visual arts sector to their 
professional activity.

Historically, the imagery of the romantic artist emerged, as already noted, with the beginning of the autonomisation of cultural production fields - notably of art forms such as literature (Bourdieu 1996) or visual arts (Heinich 1997) - in the course of the $19^{\text {th }}$ century. Although it hardly corresponds to the dominant professional reality of artists, this romantic representation still seems high in course among the interviewees themselves. Asked why they did become an artist, Swiss visual artists mostly chose the five responses "Inner calling" (92\%), "Autonomy, independence" (92\%), "Love of art" (91\%), "Self-realisation, self-awareness" (80\%) and "Talent" (80\%). These are mostly, if not exclusively, interior qualities. On the subject of the purpose of art, the answer with the highest figure is "Food for thought and emotions" (70\%), while "Subversion and criticism" or "Contradiction and irritation" only reach around one third.

Asked what artistic types and attributes apply to themselves the most, the most cited options are "Poet, philosopher" (50\%), "Inventor, creator" (45\%) and "Storyteller" (41\%). And symptomatically, among the most cited aspects for a successful art career are inner qualities such as "Hard work, persistence" (95\%), "Curiosity, inquisitiveness" (92\%), "Passion" (90\%), "Drive" (90\%), "Courage" (83\%) and "Authenticity" (81\%). The most common answer about how the interviewees would consider their success in art is also a very internal one: "Reaching my fullest potential and creating good projects" (96\%).

To deepen our analysis of representations of visual artists, we crossed the different questions on the self-presentation on official documents ${ }^{19}$ and the already described motives invoked by our interviewees as to their commitment in an artistic career. For each of these questions, we will present the trends within the sample as a whole and, in parallel, the over- or under-representation of these trends within each cluster. Our aim is to show that beyond the sometimes very evanescent character that the notion of "artist" can encompass, artistic workers' identities at work (Hughes 1996, Perrenoud and Bataille 2018) are largely dependent on their situation and the interactions in which fits their professional activity.

19 The question referred to private (or "non-public") administrative documents like tax returns documents, insurance policies or visas, on the basis of the assumption that this kind of selfpresentation would be particularly coherent with the respondents professional self-representation. 
Figure 5: Self-presentation on official documents
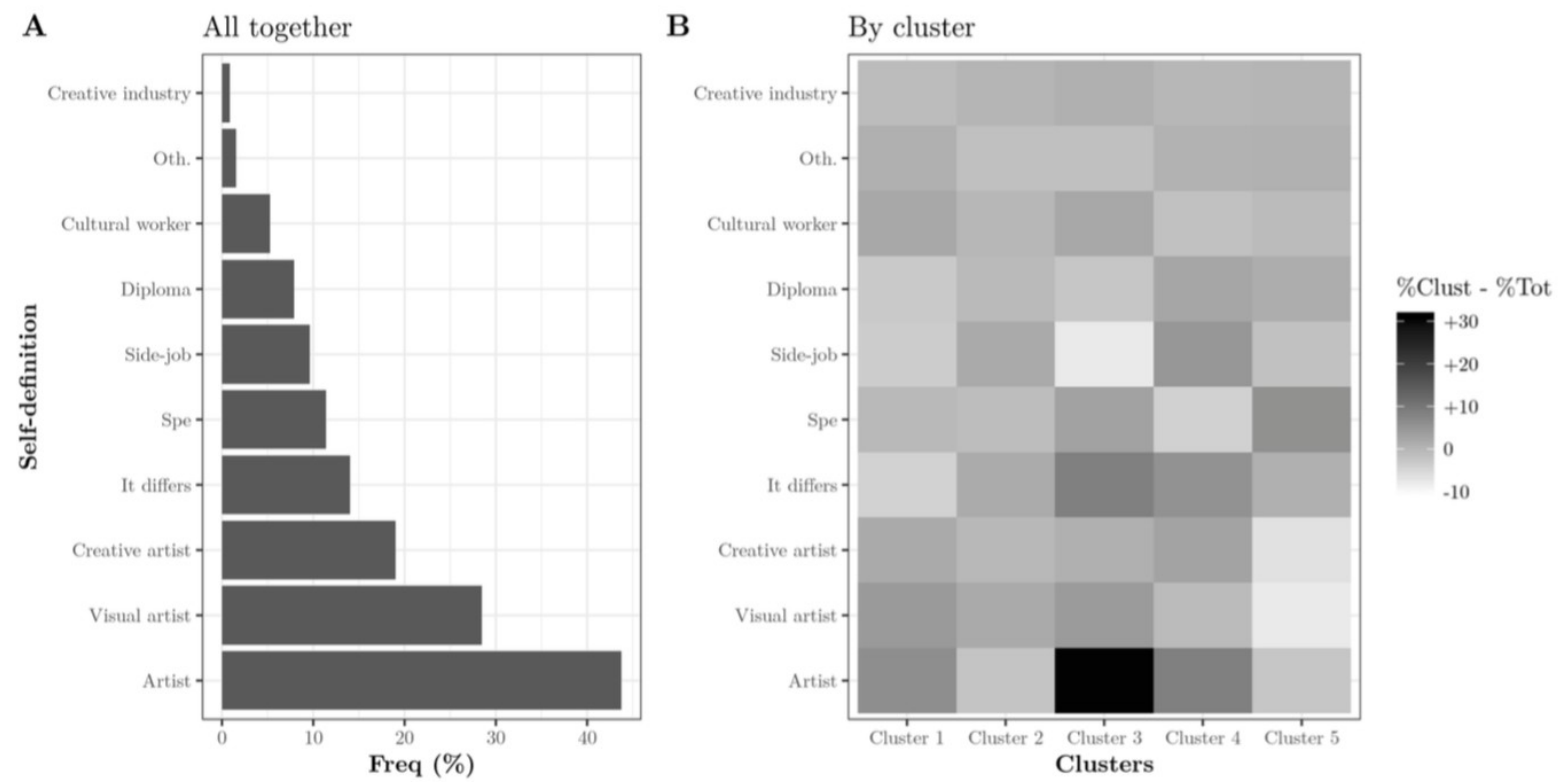

Figure 5.A represents, for example, the frequency of the different qualifiers used by our respondents to present themselves in the context of official documents related to their professional activity. We see here that it is the word "Artist" which is most often used (more than $40 \%$ of the cases). Then come such expressions as "Visual artist" and "Creative artist", who still highlight the "artistic" nature of the activity. The specialty (in the figure: modality "Spe") such as for example "photographer", "web-designer" is put forward in relatively few cases (around 10\%). The diploma is also quite rarely mentioned (8\%).

When analysing the variations of use of these different qualifiers according to the cluster of membership, it is clear that to define oneself as "artist" is above all the privilege of the members of the clusters where the artistic activity is the most profitable (the "institutional" Cluster 1 and, especially, the "market-oriented" Cluster 3, where the difference reaches 30 points). In Cluster 4 , the one at the periphery of the visual arts professional space, it is more the "Side job" or even the diploma that is used to present oneself. For Cluster 5 members, the technical specialty is more often cited in comparison with the entire sample. As the members of this Cluster are situated between the more art market-oriented pole and the outsiders pole, it may be thought that highlighting the particular know-how held by the artistic workers in question maybe aims less at commercialisation of a particular artistic vision than a technical knowledge. This would allow to get work enrolments in a segment of the labour market of the visual production relatively distant from the instances of consecration (foundation, museums, galleries ...) and populated of people little or not recognised as artists in their own right.

Figure 6.A shows in an overview the membership scale for all the items proposed by the already evoked question on motivational items which, in the opinion of visual artists, have led them to embark on the path of an artistic career. The modalities are ordered by level of relevance: the more one moves towards the lines at the 
bottom of the graph, the more the modalities mentioned apply "totally" to the way in which the respondents perceive their own career. We see here that the gradation is almost linear between the modality applying the least ("To get rich") and that applying the most (the very internal "Love of art" and "Inner calling"), following the diagonal of the table.

The least relevant modalities are those that refer to a very stereotypic vision of celebrity ("To get rich", "To become famous"), sometimes staged in certain cultural media or production, but very disconnected from the daily realities of artistic work as shown by studies. Above all, these little chosen modalities are in total opposition with the ideal of disinterestedness on which is based much of the illusio of the people who engage permanently in an artistic career (Bourdieu 1975), even on a relatively "ordinary" level (Bois and Perrenoud 2017). We already saw that the modalities appearing to be most in tune with this "romantic" ideal of the "uncreated" and "disinterested" artist ("Love of art", "Talent", "Inner calling") are the most quoted as applying to our respondents. The terms referring to the more political role and to the social change which artists often pursue ("To give back to society", "To change the world", "Political commitment", "Sense of mission") occupy a place intermediate on the scale here constituted. 


\title{
Figure 6: Motivations to become an artist
}

A

\author{
All together
}

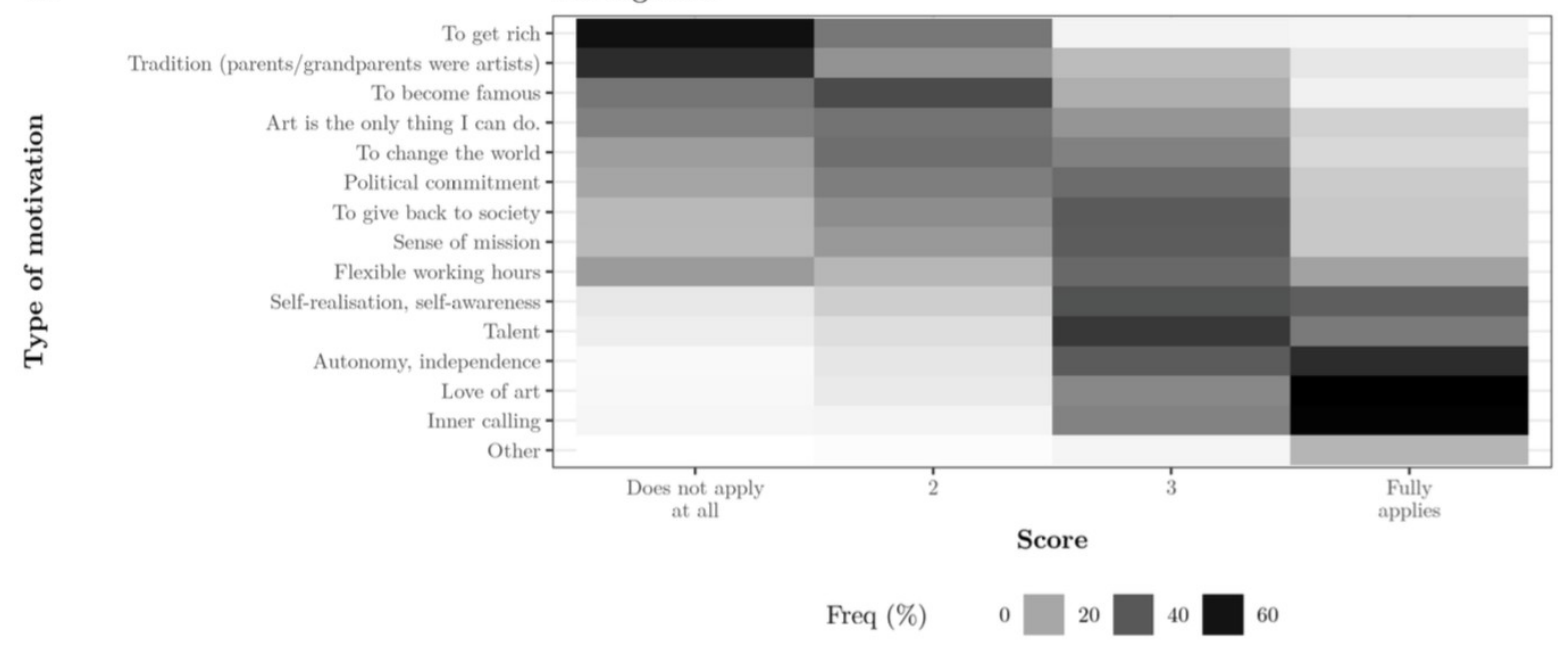

B

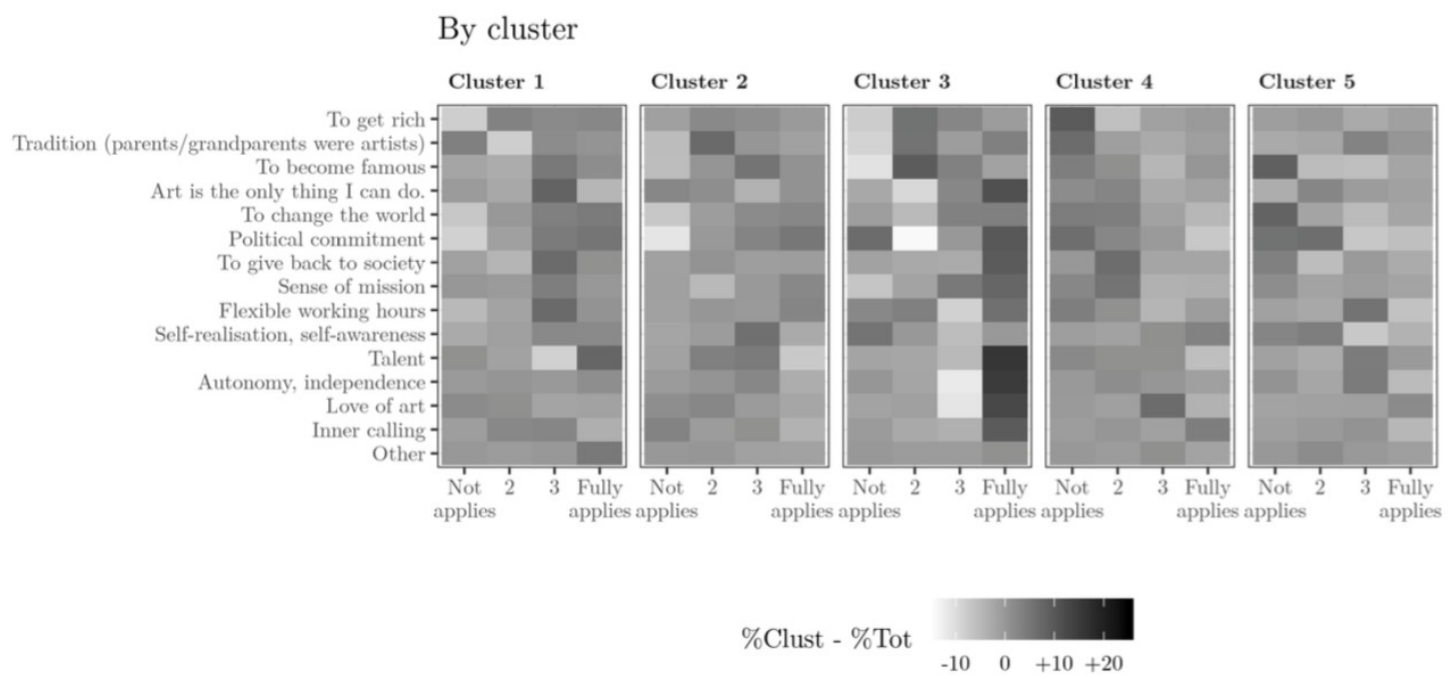

However, depending on the cluster of membership, the hierarchy of values retrospectively invoked to have motivated the artistic career-varies considerably. Interestingly, it is among the artists most committed to market logic (Cluster 3 ) that we find the proportion of respondents who most recognise themselves in the "romantic" and classical individual determinants of an artistic career, particularly the "Talent", quoted 1.25 times more often as corresponding "perfectly" to what pushed them to make a career. This again confirms that the romantic imagery of the artist historically linked to the singularity regime can be compatible with the entrepreneurial dimension (Borja and Sofio 2009). The more social and political factors are also slightly more cited within this cluster than overall. Among respondents who are more supported by foundations and public authorities (Cluster 1), the weight of "Talent" or the thirst for "Independence" in vocation seems to be less important. Here aspects like "To give back to society" but also "Flexible working hours" are more put forward. Political and social change factors are also 
slightly more often cited by Cluster 1 artists. In Cluster 4 , which regroups the marginalised and/or new entrants, "Love of art" seems to be the only motivation that stands out.

\section{Conclusion}

Our analyses showed that the space of professional positions and careers in Swiss visual arts is structured by a tripolar logic. An institutional oriented pole - where artistic activities depend on foundations, public funds and art institutions - is opposed to a market oriented pole where galleries dominate, both being at the antipodes of the third pole regrouping the non-integrated and/or marginalised.

Moreover, the market oriented pole and its competition are the most correlated to artistic independence in the perception of the professionals themselves. Interestingly then, the singularity regime is far from being outdated. Historically linked to the autonomisation of the field, the romantic (self-)representation of artists appears to be very compatible with the recent entrepreneurial artistic regime (Borja and Sofio, 2009). It would be interesting to explore this results further in regard to the classical dichotomous polarisation of the artistic field (Bourdieu 1996). In particular, it could be fertile to see how this tripolar field does intersect with the classical dichotomous polarisation of the market between the valorised pole of limited production and the profitable but less recognised pole of large scale production.

Further on, our analyses has confirmed the existence of the "gender gap" long observed in visual arts (Pasquier 1983) in the Swiss case. In view of the previous results concerning the determinants of career orientation, it appears that the cluster where women are most often underrepresented (the market oriented Cluster 3 ) is also the one where the recognition of "Talent", the devotion to the "Love of art" - in other words, the main values determining full access to the status of artist since the end of the 19th century in most of the European and North American national space - are the most important determinants of the artistic career. It is difficult to know if women remain distant from such careers because they are perceived or perceive themselves as not having the "Talent", or - more probably - if these "subjective" elements are the result of more subtle and less visible collective and informal mechanisms of co-optation (Pasquier 1983, Buscatto 2009). Following what Beaufaÿs and Krais (2005: 58, 60) observed for the academic field, one could say that the "illusio" of one's art as "way of life" and the total "availability" it demands may be conflictual with the more familial and social role often still assigned to women.

We can at least see that, by their under-representation in this professional subspace dominated by the galleries and market logic, women visual artists are a priori less likely to be given a status of creative artist at the same level as men spawning in such circles. This confirms the long observed link between visual artists' careers and the structural properties of the field of visual art and, in particular, the domination of galleries in the latter (see White and White 1965, Giuffre 1999), moreover in an era of globalisation and of specialisation in the cultural fields leading some authors to speak of a "golden age of intermediaries" (Jeanpierre and 
Roueff 2014). Last but not least, the pioneer work of Dominique Pasquier (1983) would help you go further on the discussion. From a gender perspective, artistic fields, often less formal in appearance, seem on the contrary to be more asymmetrical, since the "control" of the (often male) gatekeepers and networks regarding profitable positions and possibilities is "facilitated when criteria and rules are informal or even opaque" (Buscatto 2009: 10). Beyond the formal borders, which have largely been eliminated in this regard, there remain obstacles which are even more sly as they are "informal, less visible and cumulative at different moments of the career" (ibid., 8). The situation recalls the observation, more than 35 years ago, by Dominique Pasquier (1983: 422): "the putting away of women is done all along of their artistic curriculum, from the taking into account of their vocation to their confrontation with the professional actors of the market”.

The analyses has also revealed possible Swiss specificities. As stated at the beginning, visual arts is a field which is classically or strongly linked to market logics. This is also, and maybe even more strongly, the case in the Swiss context, where the State historically did not support arts and culture very strongly (Thévenin and Moeschler 2018), notably visual arts (Jost 1987 and 1989). The main reason is the historically rooted Swiss federalism, in which it is the cantons that formally have the sovereignty, also in cultural matters, the federal State intervening only on a facultative bases and if the authorities perceive - as it was the case for the "exception culturelle" of cinema (Moeschler 2011) - that "national interests" are at stake. Further factors are the adherence of the elites to liberalism, which results in the subsidiarity principle giving the lead in cultural matter to private initiative (Walzer 1988), and, last but not least, the will not to favour one of the three the main linguistic-cultural communities in the country (Hauser 2010).)

Success in the art market - above all economic success - seems, in Switzerland, then to be the main indicator of artistic value and individuality. It is among our most invested respondents in this segment of the professional space that one finds indeed a more important attachment to the notions of "talent", "independence" and, moreover, of devotion to the "love of art". Whereas in other national contexts such as France (Dubois 1999, Urfalino 1989) or Norway (Kleppe 2016) it is the State that appears to be the main guarantor of the autonomy and specificity of the "disinterested" nature of cultural goods, here it is quite otherwise. In the end, as our analyses has shown, it is the market logic - and above all the here dominant gallery system - and its competition that are the most correlated to artistic independence in the perception of the professionals themselves. In the end, this result indirectly points to the fundamental impact of state categories in cultural matters in the ways of representing oneself and of living as an "artist", especially at the intermediate and lower levels of the professional hierarchy (Perrenoud and Bataille 2017) - be in a somewhat different and specific way, through a State choosing to let the market be determinant in artists' living conditions and modalities of self-representation. 


\section{References}

Beaufaÿs, Sandra and Beate Krais. 2005. "Femmes dans les carriers scientifiques en Allemagne: les mécanismes cachés du pouvoir ". In Travail, genre et sociétés, $2 / 14: 49-68$.

Becker, Howard. 1982. Art Worlds. Berkeley LA/London: University of California Press.

Belting, Hans, Andrea Buddensieg. 2009. The Global Art World. Audiences, Markets and Museums, Ostfildern: Hatje Cantz.

Belting, Hans, Andrea Buddensieg, Peter Weibel (eds.). 2013. The Global Contemporary and the Rise of New Art Worlds, Cambridge/Mass.: The MIT Press.

Belting, Hans, Jacob Birken, Andrea Buddensieg. 2011. Global Studies. Mapping Contemporary Art and Culture, Ostfildern: Hatje Cantz.

Bidart, Claire, Maria Eugenia Longo and Ariel Mendez. 2013. "Time and Process: An Operational Framework for Processual Analysis ". European Sociological Review. Vol. 29, $\mathrm{n}^{\circ} 4: 743-751$.

Boltanski, Luc, Eve Chiapello. 1999. Le nouvel Esprit du Capitalisme. Paris: Gallimard.

Bourdieu, Pierre. 1975, "L'invention de La Vie d'artiste ". In Actes de la recherche en sciences sociales. Vol. $1, \mathrm{n}^{\circ} 2: 67-93$.

Bourdieu, Pierre. 1984, "Mais qui a créé les créateurs ? ".uestions de sociologie. Paris: Minuit. 207-221.

Bourdieu, Pierre. 1996 (1992). The Rules of Art. Genesis and Structure of the Literary Field. Stanford: Stanford University Press.

Buscatto, Marie. 2007. Femmes du jazz. Musicalités, féminités, marginalisations. Paris: CNRS Editions.

Buscatto, Marie. 2009. "Le plafond de verre dans tous ses éclats'. La féminisation des professions supérieures au XX $\mathrm{XX}^{\mathrm{e}}$ siècle ". In Sociologie du travail. Vol. 51(2) : 170182. [pagination refers to online version:

https://journals.openedition.org/sdt/16326]

Bram, Thursday. 2011. "10 Artists Explain How They Became Art Entrepreneurs". In American Express Company : Trends and Insights, March 2 (online :

https://www.americanexpress.com/en-us/business/trends-and-insights/articles/ 10-artists-explain-how-they-became-art-entrepreneurs- $1 / 1$.

Bureau, Marie-Christine, Marc Perrenoud and Roberta Shapiro (eds). 2009. L'artiste pluriel. Démultiplier l'activité pour vivre de son art, Lille: Presses Universitaires du Septentrion, 2009. 
Bydler, Charlotte. 2004. The Global Artworld Inc. On the Globalization of Contemporary Art. Uppsala: Acta Universitatis Upsaliensis.

Campbell, Anita. 2017. "The Trend of the Artist Entrepreneur ". In Small Business Trends, Nov. 1 (online : https://smallbiztrends.com/2008/11/the-trend-of-theartist-entrepreneur.html).

Caplin, Lee. 1980. "A Portrait of an Artist as Entrepreneur ". In Performing Arts Review, 10 (4) : 433-442.

Cliché, Danielle, Ritva Mitchell and Andreas Johannes Weisand. 2001. Pyramid or Pillars: Unveiling the Status of Women in Arts and Media Professions in Europe. Germany: ARCult Media/ERICarts/ZfKf.

Dockx, Nico, Pascal Gielen (eds.). 2015. Mobile Autonomy. Exercises in Artists' SelfOrganization. Amsterdam: Valiz.

Dubois, Vincent. 1999. La Politique Culturelle. Genèse d'une catégorie d'intervention publique. Paris: Belin.

Falcon, Julie. 2013. Social Mobility in 20th Century Switzerland. PhD-Thesis, Lausanne: University of Lausanne.

Fasche, Melanie. 2013. "Making art history-Wealthy private collectors and contemporary visual art”, In Iain Hay (ed.). Geographies of the super-rich. London: Edward Elgar. 171-185.

Freidson, Eliot. 1986. "Les professions artistiques comme défi à l'analyse sociologique ". In Revue française de sociologie, n. 27 : 431-443.

Freidson, Eliot. 1994. "Pourquoi l'art ne peut pas être une profession ". In PierreMichel Menger and Jean-Claude Passeron (eds.). L'art de la recherche. Essais en l'honneur de Raymonde Moulin, Paris: La Documentation française : 119-135.

Giuffre, Katherine. 1999. "Sandpiles of opportunity: success in the art world". In Social forces. Vol.77, $\mathrm{n}^{\circ} 3: 815-832$.

Glauser, Andrea. 2009. Verordnete Entgrenzung. Kulturpolitik, Artist-in-ResidenceProgramme und die Praxis der Kunst. Bielefeld: Transcript.

Grau, Donatien. 2013. The Age of Creation. Berlin: Sternberg.

Graw, Isabelle. 2010. High price: art between the market and celebrity culture. Berlin: Sternberg.

Hassler, Katrin. 2017, "On Gender Statistics in the Art Field and Leading Positions in the International Sphere”. In n.paradoxa : international feminist art journal, 
vol.39 : 48-55.

Hauser, Claude (ed.). 2010. Entre Culture et Politique: Pro Helvetia de 1939 - 2009. Geneva: Slatkine.

Hughes Everett C.1996. "Le Travail et Le Soi ". In Le Regard sociologique. Paris: Éditions de l'EHESS : 54-76.

Heinich, Nathalie. 1993. Du peintre à l'artiste. Artisans et académiciens à l'âge classique. Paris: Editions de Minuit.

Heinich, Nathalie. 2005. L'élite artiste. Excellence et singularité en régime démocratique. Paris: Gallimard.

Henning, Christoph, Franz Schultheis, Dieter Thomä. 2019. Kreativität als Beruf. Bielefeld: transcript.

Jacobs, Ruben. 2016. Everyone is an artist. On Authenticity, the position of the artist, and the Creative Industries. Rotterdam: V2_Publishing.

Jeanpierre, Laurent and Olivier Roueff (ed.). 2014. La culture et ses intermédiaires. Paris: Ed. des Archives contemporaines.

Jost, Hans-Ulrich. 1987. "Politique culturelle de la Confédération et valeurs nationales ". In Bernard Crettaz, Hans-Ulrich Jost and Rémy Pithon (eds.), Peuples inanimés, avez-vous donc une âme ? Images et identités suisses au $20^{\text {ème }}$ siècle. Lausanne: Université de Lausanne. 19-38.

Jost, Hans-Ulrich. 1989. "La nation, la politique et les arts ". In Schweizerische Zeitschrift für Geschichte. Vol. 39 : 293-303.

Kleppe, Bård. 2016. "The Autonomous World Reversed: Comparing Liberal Policy and Autonomy in the Performing Arts ". In International Journal of Cultural Policy. 48(3) : 387-405.

Lahire, Bernard. 2006. La Condition littéraire: La double vie des écrivains. Paris: La Découverte.

Le Feuvre, Nicky, Pierre Bataille, Maria del Río Carral, Sabine Kradolfer Morales and Marie Sautier. 2018. "The Gendered Diversification of Academic Career Paths in Comparative Perspective”. In Annalisa Murgia and Barbara Poggio (eds.). The Precarisation of Research Careers: A Comparative Gender Analysis. Londres:

Routledge. 50-80.

Le Roux, Brigitte and Henry Rouanet. 2010. Multiple Correspondence Analysis, London: SAGE.

Lindqvist, Katja. 2011. "Artist entrepreneurs ", in: Mikael Scherdin and Ivo Zander (eds.). Art Entrepreneurship. Cheltenham: Edward Elgar. 10-22. 
Lizé, Wenceslas, Delphine Naudier and Sévérine Sofio. 2014. Les stratèges de la notoriété. Intermédiaires et consécration dans les univers artistiques. Paris: Ed. des Archives contemporaines.

Menger, Pierre-Michel. 1997. Le métier de comédien. Formations, activités et carrières dans la démultiplication de soi. Paris: Ministère de la Culture et de la Communication/La Documentation Française.

Menger, Pierre-Michel. 2002. Portrait de l'artiste en travailleur. Les métamorphoses du capitalisme. Paris: Gallimard.

Menger, Pierre-Michel. 2009. Le Travail créateur. Paris: Gallimard.

Moeschler, Olivier. 2011. Cinéma suisse. Une politique culturelle en action : l'Etat, les professionnels, les publics. Lausanne: PPUR.

Moroni, Isabelle. 2017. " De la périphérie à la scène internationale. Parcours d'artistes à l'épreuve de la mobilité ". In André Ducret, Andrea Glauser, Olivier Moeschler, and Valérie Rolle (eds.), Swiss Journal of Sociology, "Art, Work and (De-)regulation" (special issue). 357-374.

Pasquier, Dominique. 1983. "Carrières de femmes: l'art et la manière ". In Sociologie du travail. Vol. 25(4) : 418-431.

Perrenoud, Marc and Pierre Bataille. 2018. "Comment être musicien ? Figures professionnelles des musiciens ordinaires en France et en Suisse ". In SociologieS, "Identité au travail, identités professionnelles : quel(s) rapport(s)? " (online : https://journals.openedition.org/sociologies/8882).

Perrenoud, Marc and Pierre Bataille. 2017. "Artist, Craftsman, Teacher: "Being a Musician" in France and Switzerland ". In Popular Music and Society, 2017. Vol. 40, $\mathrm{n}^{\circ} 5$ : 592-604.

Perrenoud, Marc and Géraldine Bois. 2017. "Artistes ordinaires : du paradoxe au paradigme ? Variations autour d'un concept et de ses prolongements ". Biens Symboliques/Symbolic Goods. № 1 (online:

http://revue.biens-symboliques.net/88).

Perrenoud, Marc and Jérôme Chapuis. 2016. "Des arrangements féminins ambivalents: musiques actuelles en Suisse romande ". In Ethnologie Française. Vol. $46, \mathrm{n}^{\circ} 1: 71-82$.

Provansal, Mathilde. 2018. "Carrières des plasticiennes sous contrainte des normes de genre des intermédiaires ". In Sylvie Octobre and Frédérique Patureau (eds.). Normes de genre dans les institutions culturelles. Paris: La Documentation française : 61-74.

Quemin, Alain. 2013. Les Stars de l'art contemporain: notoriété et consécration 
artistiques dans les arts visuels. Paris: Éditions du CNRS.

Quemin, Alain. 2014. "International Fame, Success and Consecration in the Visual Arts. A Sociological Perspective on Two Rankings of the 'Top 100 Artists in the World': The Kunstkompass and the Capital Kunstmarkt Kompass. In Dagmar Danko, Olivier Moeschler and Florian Schumacher. Perspektiven der Kunstsoziologie II. Kunst und Öffentlichkeit. Wiesbaden: Springer VS. 345-364.

Reckwitz, Andreas. 2012. Die Erfindung der Kreativität. Frankfurt am Main: Suhrkamp.

Reilly Maura. 2015. „Taking the Measure of Sexism: Facts, Figures, and Fixes“. In ARTnews, May 26 [online: http://www.artnews.com/2015/05/26/taking-themeasure-of-sexism-facts-figures-and-fixes/].

Rolle, Valérie and Olivier Moeschler. 2014. De l'école à la scène. Entrer dans le métier de comédien-ne. Lausanne: Editions Antipodes.

Sinigaglia-Amadio, Sabrina et Jérémy Sinigaglia. 2015. "Tempo de la vie d'artiste : genre et concurrence des temps professionnels et domestiques ". In Cahiers $d u$ Genre. November 2015, n 59 : 195-215.

Studer, Matthias. 2013. "Weighted Cluster Library Manual: A Practical Guide to Creating Typologies of Trajectories in the Social Sciences with R ", LIVES Working Papers. Vol. 2013, n $24: 1-32$.

Thévenin, Olivier and Olivier Moeschler. 2018. "The Changing Role of the Cultural State: Art Worlds and New Markets. A Comparison of France and Switzerland ". In Victoria D. Alexander, Samuli Hägg, Simo Häyrynen and Erkki Sevänen (eds.), Art and the Challenge of Markets. Vol. 1, London: Palgrave Macmillan. 125-153.

Throsby, David and Virginia Hollister. 2003. Don't Give Up Your Day Job: An Economic Study of Professional Artists in Australia. Sydney: Australia Council (online : https://www.australiacouncil.gov.au/workspace/uploads/files/research/ entire document-54325d2a023c8.pdf).

Urfalino, Philippe. 1989. "Les Politiques Culturelles: Mécénat Caché et Académies Invisibles ". In L'Année sociologique. Vol. 39 : 81-109.

Walzer, Pierre-Olivier. 1988. A vot' bon cour, m' sieu'dames: petit traité de mendicité culturelle. Genève: Ed. Zoé.

Weckerle, Christoph and Simon Grand. 2018. $3^{\text {rd }}$ Creative Economies Report Switzerland 2018. Zurich: ZHdK.

Weibel, Peter, Andrea Buddensieg (eds.). 2007. Contemporary Art and the Museum: A Global Perspective, Ostfildern: Hatje Cantz.

White Harrison C., Cynthia A. White. 1965. Canvases and careers: institutional 
change in the French painting world. Hoboken: Wiley.

\section{Annexes}

Table: Illustrative modalities

\begin{tabular}{lll}
\hline Variables \& modalities & $\mathrm{N}$ & $\%$ \\
\hline Sex & 178 & 39.7 \\
Male & 270 & 60.3 \\
Female & & \\
Diploma & 189 & 42.0 \\
$\quad$ Other & 261 & 58.0 \\
Tertiary & & \\
Age & 55 & 12.1 \\
-30 & 67 & 14.7 \\
$31-40$ & 90 & 19.7 \\
$41-50$ & 134 & 29.4 \\
$51-60$ & 110 & 24.1 \\
$>60$ & & \\
Partner & 78 & 22.7 \\
works as artist & 45 & 13.1 \\
$\quad$ works in the cultural field & 210 & 61.0 \\
$\quad$ works in another field & 11 & 3.2 \\
$\quad$ no partner & 457 & 100 \\
\hline Total & & \\
\hline
\end{tabular}

